\title{
Kendala Yang Dihadapi Mahasiswa Pendidikan Ekonomi Universitas Pamulang Dalam Mengikuti Perkuliahan Daring Pada Mata Kuliah Seminar Proposal Penelitian Selama Masa Pandemi Covid-19
}

\author{
Syafaatul Hidayati ${ }^{1}$, \\ ${ }^{1}$ Prodi Pendidikan Ekonomi, FKIP Universitas Pamulang \\ email: dosen00861@unpam.ac.id
}

Received: 10 Maret, 2020; Accepted: 17 Mei, 2020; Published: 27 Juni, 2020

\begin{abstract}
Abstrak
Selama pandemi Covid-19 universitas mengubah kegiatan perkuliahannya dari yang semula melalui tatap muka secara langsung ke perkuliahan daring. Demikian halnya dengan peneliti juga merancang perkuliahan dengan sedemikian rupa supaya tujuan dari mata kuliah seminar proposal penelitian bisa tercapai dengan baik. Dalam pelaksanaannya mahasiswa mengalami kendala dalam perkuliahan daring. Tujuan penelitian ini adalah untuk mengetahui kendala yang dihadapi mahasiswa pendidikan ekonomi Universitas Pamulang (UNPAM) dalam mengikuti perkuliahan daring pada mata kuliah seminar proposal penelitian selama masa pandemi Covid-19. Metode yang dipakai dalam penelitian ini adalah metode penelitian kualitatif deskriptif. Responden dalam penelitian ini adalah 10 orang mahasiswa Program Studi S1 Pendidikan Ekonomi Fakultas Keguruan dan Ilmu Pendidikan (FKIP) Universitas Pamulang (UNPAM) semester VI yang menempuh mata kuliah seminar proposal penelitian. Berdasarkan hasil penelitian terhadap kendala yang dihadapi mahasiswa pendidikan ekonomi universitas Pamulang (UNPAM) dalam mengikuti perkuliahan daring pada mata kuliah seminar proposal penelitian selama masa pandemi Covid-19, maka dapat dibuat kesimpulan bahwa terdapat kendala internal dan kendala eksternal yang dihadapi oleh mahasiswa. Kata Kunci: Kendala, Perkuliahan Daring, Mahasiswa
\end{abstract}

\begin{abstract}
During the Covid-19 pandemic, the university changed the lecture activities from the original through face-to-face meetings to online lectures. Likewise, researchers also design lectures in such a way that the objectives of the seminar on research proposals can be achieved properly. In the implementation, students face problem in online lectures. The purpose of this study is to determine the obstacles faced by students of economic education at the University of Pamulang (UNPAM) in attending online lectures in the research proposal seminar course during the Covid-19 pandemic. The method used in this research is descriptive qualitative research method. Respondents in this study were 10 students of the S1 Educational Economics Study Program Faculty of Teacher Training and Education (FKIP) Pamulang University (UNPAM) semester VI who took the research proposal seminar course. Based on the results of research on the obstacles faced by Pamulang University economic education students (UNPAM) in attending online lectures in the seminar course for research proposals during
\end{abstract}


the Covid-19 pandemic, it can be concluded that there are internal and external constraints faced by students.

Keywords: Obstacles, Online Lectures, Students

\section{PENDAHULUAN}

Undang-Undang RI No.20 tahun 2003 tentang Sistem Pendidikan Nasional, Bab 1, Pasal 1 yang menyatakan bahwa pendidikan adalah usaha sadar dan terencana untuk mewujudkan suasana belajar dan proses pembelajaran agar peserta didik secara aktif mengembangkan potensi dirinya untuk memiliki kekuatan spiritual keagamaan, pengendalian diri, kepribadian, kecerdasan, akhlak mulia, serta keterampilan yang diperlukan dirinya, masyarakat, bangsa dan negara.

Perkembangan teknologi informasi dalam dunia pendidikan mulai menunjukkan perubahan yang signifikan. Dalam hal ini dapat kita lihat bahwa banyak sekali perubahan dan hal yang berbeda dari pada sebelumnya. Di era digital saat ini faktor jarak dan waktu bukanlah suatu penghalang yang berarti dalam menimba ilmu. Berbagai aplikasi sudah ada untuk memfasilitasinya. (Uno, 2016:153) menyatakan bahwa dalam proses belajar mengajar peran penting teknologi pendidikan sangatlah penting dalam upaya menunjang pembelajaran.

Dunia Pendidikan Indonesia akan memasuki keadaan new normal dimana kebiasaan lama dalam pelaksanaan pendidikan sudah tidak bisa menjadi suatu patokan utama. Hal ini disebabkan karena perubahan dunia yang terjadi dengan begitu cepat. Dengan demikian akan banyak penyesuaian-penyesuaian yang seharusnya dilakukan pada dunia pendidikan Indonesia. Hal tersebut bisa dimulai dari pelaksanaan pembelajaran, termasuk pelatihan yang ditujukan untuk para pendidik.

Pandemi COVID-19 telah menyadarkan kita supaya terus adaptif terhadap perubahan. Adapun kemauan untuk belajar dalam situasi kondisi apapun merupakan salah satu kunci pokok supaya pendidikan dapat terus berjalan dengan baik. Adaptasi tersebut harus dilakukan supaya tetap memberikan hak pendidikan. Sementara itu total belajar mandiri tidak dapat berjalan dengan sempurna. Hal ini disebabkan karena tingkat litrerasi Indonesia masih rendah. Berdasarkan data skor 
Programme for International Students Assessment (PISA) tahun 2015 pada tingkat literasi yang meliputi tiga aspek; membaca, kemampuan matematika, dan kemampuan sain, masih berada pada peringkat 10 besar terbawah yaitu peringkat ke-62 dari 72 negara anggota Orgnization for Economic Cooperation and Development (OECD).

. Rendahnya literasi masyarakat menyebabkan total belajar masih mandiri masih tidak bisa berjalan dengan sempurna. Masih banyak permasalahan yang muncul di lapangan yang perlu dituntaskan supaya tercapai tujuan pendidikan dengan baik. Hal tersebut menguatkan opini bahwa sesungguhnya kehadiran seorang guru jelas tidak dapat digantikan oleh mesin secanggih apapun. Dalam hal ini perannya akan dibutuhkan, meskipun yang kita lihat sarana prasarana dan juga bahan ajar yang tersedia di dunia maya (internet) sangat banyak tak terhitung jumlahnya. Oleh karena itu, proses belajar mengajar yang terjadi dari rumah tetap dibutuhkan keaktifan, kreativitas dan inovasi dari seorang guru supaya pembelajaran tetap menarik, menyenangkan dan mudah dicerna.

Demikian halnya Universitas Pamulang (UNPAM) sebagai salah satu perguruan tinggi swasta yang maju dan berkembang di tengah era digital ini. UNPAM aktif mengikuti perkembangan termasuk dalam kegiatan belajar mengajar. Perkembangan teknologi informasi dan komunikasi sangat berdampak terhadap penggunaan alat bantu mengajar seperti komputer dan internet, contohnya adalah e-learning (Ekawati, 2018).

Sebelum pandemi COVID-19 ada UNPAM sudah melakukan kegiatan perkuliahan online learning melalui web e-learning yang sudah dirancang oleh tim LP3 dan IT Center. Dengan demikian, selain mahasiswa melakukan perkuliahan tatap muka di kelas UNPAM juga memberikan inovasi pembelajaran dengan perkuliahan online learning. Hal ini juga mendapatkan tanggapan positif dari mahasiswa mengingat banyak mahasiswa UNPAM berasal dari kalangan dengan profesi sebagai pekerja.

Peneliti sebagai pengampu mata kuliah seminar proposal penelitian juga berusaha melakukan inovasi dalam kegiatan pembelajaran. Hal ini dilakukan mengingat mata kuliah seminar proposal penelitian adalah mata kuliah dari 
rumpun research. Mata kuliah ini menawarkan kemampuan dalam mengkomunikasikan hasil proposal penelitian berdasarkan pertimbangan keilmuan pendidikan ekonomi dan kaidah penulisan karya tulis ilmiah dan secara mandiri dapat bertanggung jawab pada pekerjaannya serta dapat diberi tanggung jawab terhadap pencapaian dari hasil kerjanya, estetis, komunikatif, apresiatif dan partisipatif serta etis.

Cakupan dari mata kuliah seminar proposal penelitian ini yang meliputi: (1) tata cara seminar proposal dan etika presentasi; (2) quasi eksperimen; (3) Penelitian Tindakan Kelas (PTK); (4) penelitian kuantitatif; (5) penelitian kualitatif; dan (6) penelitian dan pengembangan. Adapun tugas yang wajib dikerjakan oleh mahasiswa yang menempuh mata kuliah ini diantaranya: (1) menyusun proposal penelitian; (2) sebagai penyeminar atau penyaji; dan (3) sebagai penguji seminar. Dengan demikian setelah mengikuti mata kuliah ini mahasiswa dapat menghasilkan produk berupa proposal penelitian skripsi yang nantinya siap untuk diujikan.

Dalam pelaksanaanya, mata kuliah ini disetting layaknya ujian seminar proposal penelitian. Penyaji adalah dari yang punya proposal sendiri dan penguji dari dua orang teman kelas yang ditunjuk oleh dosen dengan cara lotre untuk menjadi penguji. Dalam hal ini setiap mahasiswa mempunyai kesempatan satu kali menjadi penyaji dan dua kali menjadi penguji. Kedudukan dosen disini adalah meluruskan pertanyaan dari penguji, melakukan koreksi kesesuaian proposal yang sudah disusun oleh penyaji dengan kaidah penulisan karya tulis ilmiah, memberikan kritik dan saran yang membangun demi kesempurnaan proposal skripsi yang telah disusun. Adapun pelaksanaan perkuliahan yang disetting seperti layaknya ujian seminar proposal penelitian dengan tujuan supaya mahasiswa mempunyai gambaran mengenai pelaksanaan ujian seminar proposal penelitian yang akan mereka lalui nanti. Dengan demikian mahasiswa terlatih dalam mempresentasikan proposal mereka, menjawab pertanyaan penguji dan juga bisa menyempurnakan proposalnya berdasarkan saran dari penguji masing-masing dan juga dosen. 
Berdasarkan pengamatan dan juga wawancara tidak terstruktur antara peneliti dengan beberapa mahasiswa pendidikan ekonomi universitas Pamulang (UNPAM diperoleh informasi bahwa ada beberapa kendala yang mereka alami dalam mengikuti perkuliahan daring pada mata kuliah seminar proposal penelitian selama masa pandemi Covid-19 yang sudah berlangsung selama ini. Kajian daring sebelumnya sudah dilakukan oleh beberapa peneliti diantaranya Yanti, et all, (2020), W Darmalaksana, et all (2020) dan Sanjaya (2020).

Oleh sebab itu, berbagai kendala yang dihadapi mahasiswa pendidikan ekonomi universitas Pamulang (UNPAM) dalam mengikuti perkuliahan daring pada mata kuliah seminar proposal penelitian selama masa pandemi Covid-19 akan diidentifikasi dan dianalisis lebih lanjut.

Sistem perkuliahan daring yang kita kenal saat ini dikembangkan oleh Kementerian Pendidikan dan Kebudayaan Republik Indonesia melalui Program Kuliah Daring Indonesia Terbuka dan Terpadu (KDITT). Menurut Kementerian Pendidikan dan Kebudayaan RI (2014: 1) KDITT merupakan program pemerintah dalam menjangkau pelajar skala nasional.

Najib, Mada, \& Model (2018) menyatakan bahwa karakterisktik kuliah daring yang berbeda dengan pembelajaran yang dilaksanakan di kelas (luring) membutuhkan strategi khusus di dalam menyediakan sarana prasarana komunikasi atau interaksi yang baik diantara mahasiswa dengan dosen serta diantara satu dengan mahasiswa yang lain. Terdapat dua jenis komunikasi yang secara umum digunakan dalam perkuliahan daring, yaitu komunikasi sinkron dan asinkron.

Harjanto dan Sumunar (2018) mengungkapkan bahwa pembelajaran daring merupakan suatu proses transformasi pendidikan dari konvensional ke dalam bentuk digital, sehingga hal tersebut mempunyai tantangan dan juga peluang tersendiri. Adanya kendala yang di dalam proses pembelajaran daring harus segera bisa ditemukan solusinya. Demikian lembaga LPTK bisa memetakan proyeksi pembelajaran melalui sistem daring ke depannya.

Ada beberapa faktor yang dapat mendukung keberhasilan sistem pembelajaran daring. Dari berbagai faktor yang menjadi kunci sukses dari pembelajaran daring ialah ketersediaan sarana dan prasarana yang mendukung 
(Pangondian et all, 2019). Dengan demikian Rusdiana dan Nugroho (2020) mengungkapkan bahwa dukungan dari perguruan tinggi dan juga dosen menjadi hal yang penting dalam upaya mendukung keberhasilan dari pembelajaran daring.

\section{METODE}

Metode yang dipakai dalam penelitian ini adalah metode penelitian kualitatif deskriptif. Menurut Moleong (2017:6) penelitian kualitatif adalah penelitian yang bermaksud untuk memahami penomena tentang apa yang dialami oleh subjek peneliti misalnya perilaku, persepsi, motivasi, tindakan dan lain-lain. Secara holistik, dan dengan cara deskripsi dalam bentuk kata-kata dan bahasa, pada suatu konteks khusus yang alamiah dan dengan memanfaatkan berbagai metode ilmiah.

Alasan peneliti memilih metode penelitian tersebut adalah karena hal ini sangat berkaitan dengan judul dan rumusan masalah yang diungkapkan peneliti yang terdapat di pendahuluan yang lebih mengarah pada kendala yang dihadapi mahasiswa pendidikan ekonomi universitas Pamulang (UNPAM) dalam mengikuti perkuliahan daring pada mata kuliah seminar proposal penelitian selama masa pandemi Covid-19, dimana peneliti meyakini bahwa permasalahan yang dihadapi oleh setiap mahasiswa akan berbeda. Hal ini sesuai dengan tujuan dari penelitian ini mengeksplorasi apa saja kendala yang dihadapi mahasiswa pendidikan ekonomi universitas Pamulang (UNPAM) dalam mengikuti perkuliahan daring pada mata kuliah seminar proposal penelitian selama masa pandemi Covid-19.

Lokasi Penelitian ini dilaksanakan pada mahasiswa Program Studi S1 Pendidikan Ekonomi Fakultas Keguruan dan Ilmu Pendidikan (FKIP) Universitas Pamulang (UNPAM) semester VI. Alamat Jl. Raya Puspiptek, Buaran, Pamulang, Kota Tangerang Selatan, Banten 15310.

Sumber data yang digunakan oleh peneliti diantaranya: (1) sumber data primer, yakni data yang diperoleh peneliti dari responden langsung; dan (2) sumber data sekunder, yakni data yang diperoleh peneliti secara tidak langsung. 
Dalam penelitian ini sumber data sekunder diperoleh peneliti dari dokumen pribadi dan juga jurnal yang berhubungan dengan penelitian yang dilakukan.

Responden dalam penelitian ini adalah mahasiswa Program Studi S1 Pendidikan Ekonomi Fakultas Keguruan dan Ilmu Pendidikan (FKIP) universitas Pamulang (UNPAM) semester VI yang menempuh mata kuliah seminar proposal penelitian. Berikut tabel mengenai sumber data dan teknik pengumpulan data.

Tabel 1 Sumber data dan teknik pengumpulan data

\begin{tabular}{cllll}
\hline No. & \multicolumn{1}{c}{ Parameter } & \multicolumn{1}{c}{ Sumber } & Teknik & Alat \\
\hline 1. & Kendala dalam & 4 orang mahasiswa & Observasi, & Kamera, alat \\
& mengikuti & regular A yang terdiri & Wawancara & tulis, perekam \\
perkuliahan & dari 2 orang mahasiswa & Dokumentasi & dan pedoman \\
daring & kelas 06PIEP001 dan 2 & & \\
& orang mahasiswa & & \\
& 06PIEP002. Selain itu 6 & & \\
& orang mahasiswa & \\
Reguler B yang terdiri & \\
dari 2 orang mahasiswa & & \\
& kelas 06PIEM001, 2 & & \\
& orang mahasiswa kelas & & \\
& 06PIEM002 dan 2 orang & & \\
& mahasiswa kelas & & \\
& 06PIEM003. &
\end{tabular}

Sumber: Diolah oleh Peneliti (2020)

Teknik analisis data dalam penelitian ini dilakukan pada saat pengumpulan data dalam periode waktu tertentu. Adapun peneliti melakukan penelitian selama kurun waktu dua bulan. Miles and Huberman (dalam Sugiyono, 2017:246) menyatakan bahwa aktifitas dari analisis data kualitatif itu dilakukan oleh peneliti secara interaktif dan waktunya berlangsung secara terus-menerus sampai dinyatakan tuntas, sehingga nantinya data yang diperoleh tidak jenuh. Adapun aktivitas dalam analisis data dalam penelitian ini adalah data Reduction, data Display dan data Conclusion Drawing/Verification.

\section{HASIL DAN PEMBAHASAN}

\section{Hasil Penelitian}

Data dari hasil penelitian ini diperoleh peneliti melalui teknik wawancara, observasi dan juga dokumentasi terhadap 10 orang responden yang terpilih dari mahasiswa Program Studi S1 Pendidikan Ekonomi Fakultas Keguruan dan Ilmu 
Pendidikan (FKIP) universitas Pamulang (UNPAM) semester VI yang menempuh mata kuliah seminar proposal penelitian.

Ada beberapa kendala yang dihadapi mahasiswa pendidikan ekonomi universitas Pamulang (UNPAM) dalam mengikuti perkuliahan daring pada mata kuliah seminar proposal penelitian selama masa pandemi Covid-19. Kendala tersebut dapat dijabarkan secara rinci sebagai berikut.

1. Kendala internal

Kendala internal muncul dalam diri mahasiswa sendiri. Dalam hal ini kendala yang dialami mahasiswa meliputi kemampuan dalam menggunakan IT dan kemampuan kendala mahasiswa dalam memahami materi tidak sama. Kecanggihan teknologi tidak membuat mahasiswa melek teknologi secara keseluruhan. Masih ada mahasiswa yang masih gagap teknologi. Ini sangat menghambat kelancaran perkuliahan. Misalnya yang sering dialami mahasiswa adalah tidak mengetahui cara share screen saat perkuliahan melalui aplikasi zoom. Ini dapat menghambat kelancaran dalam proses perkuliahan daring. Disamping itu sebagian besar responden juga mengalami kendala pemahaman materi. Menurut mereka lebih enak bertatap muka langsung dengan dosen, karena dengan tatap muka lebih bisa memahami materi. Dengan tatap muka mahasiswa bisa bertanya langsung kepada dosen apabila ada materi yang tidak dipahami.

2. Kendala eksternal

Ada beberapa kendala eksternal yang dihadapi oleh mahasiswa. Beberapa kendala tersebut diuraikan sebagai berikut. Pertama, kendala jaringan internet. Semua responden menyatakan bahwa mereka mengalami kendala jaringan. Menurut mereka tidak semua daerah jaringan internetnya baik, meskipun dari provider yang sama. Ini menjadi kendala utama mengingat perkuliahan daring yang dibutuhkan adalah internet. Kedua, kendala kuota yang terbatas. Perkuliahan daring khususnya melalui teleconference via zoom membutuhkan quota yang tidak sedikit. Sementara itu keadaan ekonomi saat pandemi Covid19 tidak stabil. Ini menjadi hambatan juga bagi mahasiswa mengingat mereka banyak menggantungkan biaya kuliah dari orang tua. Ketiga, kendala fasilitas 
yang tidak merata. Masih ada beberapa orang mahasiswa yang tidak mempunyai ponsel pintar atau bahkan laptop serta komputer. Ini menjadi kendala tersendiri bagi keterlaksanaannya perkuliahan daring dengan baik.

\section{Pembahasan}

Peraturan mengenai proses belajar secara mandiri dari rumah secara jelas telah diatur dalam Surat Edaran Mendikbud No. 4 Tahun 2020 tentang Pelaksanaan Kebijakan Pendidikan dalam Masa Darurat Penyebaran Coronavirus Disease (Covid-2019). Dengan demikian universitas juga mengubah kegiatan perkuliahannya dari yang semula melalui tatap muka secara langsung ke perkuliahan daring melalui situs website yang telah disediakan kampus masingmasing. Disamping itu perkuliahan daring juga dilakukan dengan memanfaatkan Moodle sebagai aplikasi Learning Management System yang dapat menyediakan fitur kegiatan pembelajaran kooperatif dan kolaboratif secara lengkap bagi para dosen, di mana fiitur ini dipilih sendiri oleh dosen untuk melaksanakan perkuliahan secara daring.

Aydin \& Gumus (2016) menyatakan bahwa kesuksesan dalam pembelajaran secara daring sangat tergantung pada partisipasi pembelajar, aktifitas belajar dan juga interaksi yang terjadi di antara pembelajar. Oleh karena itu selama pandemi Covid-19 peneliti merancang perkuliahan dengan sedimikian rupa supaya tujuan dari mata kuliah seminar proposal penelitian bisa tercapai.

Peneliti melaksanakan perkuliahan melalui web e learning yang sudah disediakan oleh pihak kampus di mana dalam web tersebut mahasiswa sudah bisa mengakses materi yang sudah menjadi rujukan dari pusat, yaitu LP3. Biasanya yang menjadi rujukan adalah modul yang sudah dirancang dosen dan ber ISBN serta mempunyai HKI. Dalam web e learning dosen dan mahasiswa bisa melakukan kegiatan diskusi dalam forum diskusi sesuai waktu yang telah terjadwal. Selain itu mahasiswa juga bisa mengakses soal pengayaan dari mata kuliah. 


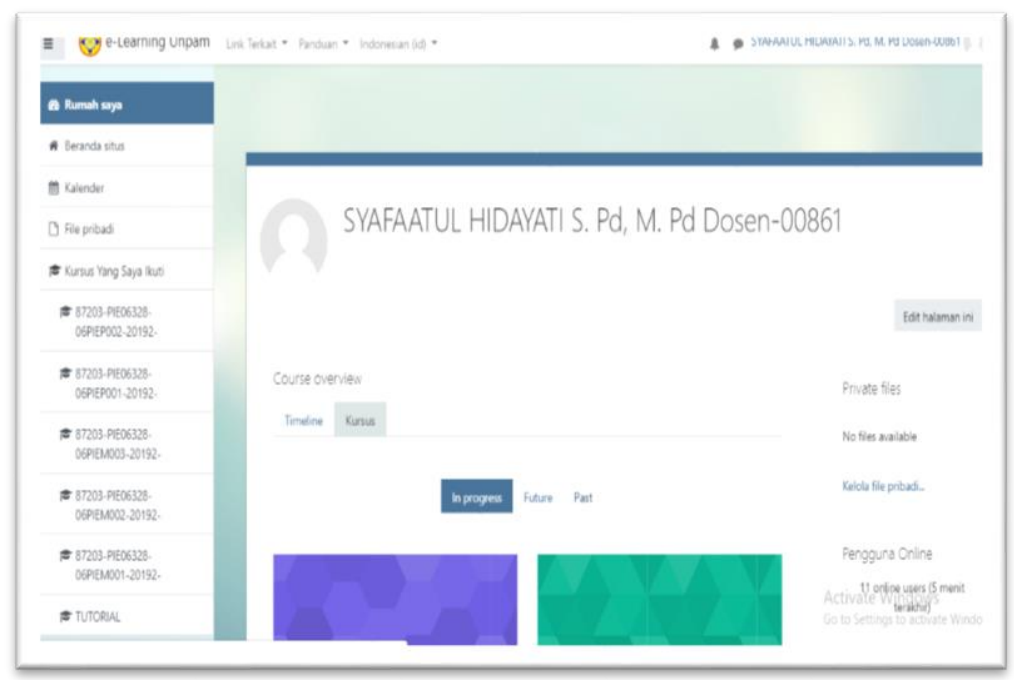

Gambar 1 Perkuliahan Daring melalui Web E-Learning

Sumber: Dokumentasi Peneliti (2020)

Perkuliahan daring juga dilakukan peneliti dengan membetuk WhatsApp Group (AG) dan juga via email untuk memberikan kemudahan kepada mahasiswa dalam konsultasi revisi proposal penelitian. Disamping itu peneliti juga melaksanakan perkuliahan dengan layanan teleconference via zoom untuk memberikan kesempatan mahasiswa mempresentasikan proposal penelitiannya. Pelaksanaan perkuliahan dengan layanan teleconference via zoom menjadi salah satu alternatif yang dipandang efektif dalam melaksanakan perkuliahan daring pada mata kuliah seminar proposal penelitian selama masa pandemi Covid-19.

Gambar 2 Perkuliahan melalui Teleconference Via Zoom

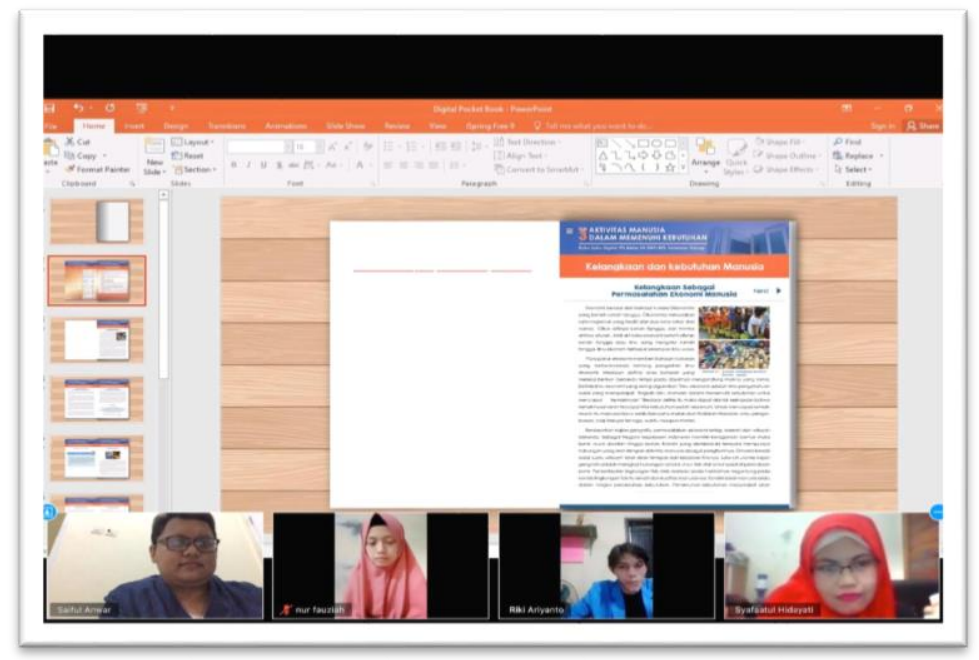

Sumber: Dokumentasi Peneliti (2020) 
Zoom dipilih oleh peneliti disebabkan karena beberapa hal diantaranya sebagai berikut. Pertama, aplikasinya gratis dan bebas digunakan. Kedua, bisa menampung peserta dalam jumlah yang banyak dengan durasi waktu 40 menit setiap pertemuan. Ketiga, aplikasi zoom bisa memastikan secara langsung kehadiran dan juga partisipasi mahasiswa. Keempat, dalam aplikasi ini ada fitur berbagi layar yang dapat digunakan dosen dan khususnya penyaji dalam menayangkan bahan presentasi proposal penelitiannya dan video atau file, sehingga perkuliahan seminar proposal penelitian dapat dilaksanakan dengan baik.

Keberhasilan perkuliahan daring didukung oleh beberapa komponen yang ada antara lain dari pihak mahasiswa, dosen, sumber belajar, maupun teknologi informasi yang ada. Beberapa komponen yang ada tersebut harus terintegrasi dengan baik. Hal ini bertujuan supaya nantinya tujuan perkuliahan dapat tercapai dengan baik dan juga dapat berpengaruh kepada output lulusan yang dihasilkan juga berkualitas.

\section{KESIMPULAN}

Berdasarkan hasil penelitian terhadap kendala yang dihadapi mahasiswa pendidikan ekonomi Universitas Pamulang (UNPAM) dalam mengikuti perkuliahan daring pada mata kuliah seminar proposal penelitian selama masa pandemi Covid-19, maka dapat dibuat kesimpulan sebagai berikut. 1). Kendala internal muncul dalam diri mahasiswa sendiri. Dalam hal ini kendala yang dialami mahasiswa meliputi kemampuan dalam menggunakan IT dan kemampuan mahasiswa dalam memahami materi tidak sama. 2). Kendala eksternal yang dihadapi oleh mahasiswa antara lain: (a) kendala jaringan; (b) kendala kuota yang terbatas; dan (c) kendala fasilitas yang tidak merata.

\section{DAFTAR RUJUKAN}

Aydin, I. E \& Gumus, S. 2016. Sense of Clasroom Community and Team Development Process In Online Learning. Turkish Online Journal of Distance Education (TOJDE), (17), (1), (5), 60-77.

Darmalaksana, W., Hambali, R., Masrur, A., \& Muhlas. 2020. Analisis Pembelajaran Online Masa WFH Pandemic Covid-19 sebagai Tantangan 
Pemimpin Digital Abad 21. Karya Tulis Ilmiah (KTI) Masa Work From Home (WFH) Covid-19 UIN Sunan Gunung Djati Bandung, 1-12.

Ekawati, Noor Emmy. 2018. Application of Blended Learning with Edmodo Application Based on PDEODE Learning Strategy to Increase Student Learning Achievement. Jurnal Ilmiah Pendidikan MIPA Vol. 8, No. 1, April 2018, pp. 7-16 -ISSN: 2088-351X.

Harjanto, T., \& Sumunar, D. S. E. W. 2018. Tantangan Dan Peluang Pembelajaran Dalam Jaringan: Studi Kasus Implementas Elok (ELearning: Open For Knowledge Sharing) Pada Mahasiswa Profesi Ners. Jurnal Keperawatan Respati Yogyakarta, 5, 24-28.

Kementerian Pendidikan dan Kebudayaan RI. Panduan Pengembangan dan Penyelenggaraan KDITT. Jakarta: Kemendikbud, 2014.

Moleong, Lexy J. 2017. Metode Penelitian Kualitatif, cetakan ke-36. Bandung: PT. Remaja Rosdakarya Offset.

Najib, W., Mada, U. G., \& Model, E. 2018. Analisis Penerapan Pembelajaran Daring Pada Mata Kuliah Jaringan Komputer dengan Metode Massive Open Online Course ( MOOC ). (November 2017).

Pangondian, R. A., Santosa, P. I., \& Nugroho, E. (2019, February). Faktor-Faktor Yang Mempengaruhi Kesuksesan Pembelajaran Daring Dalam Revolusi Industri 4.0. In Seminar Nasional Teknologi Komputer \& Sains (SAINTEKS) (Vol. 1, No. 1).

Rusdiana, E., \& Nugroho, A. 2020. Respon Mahasiswa Pada Pembelajaran Daring Bagi Mahasiswa Mata Kuliah Pengantar Hukum Indonesia. UNESA. Integralistik, 31(1), 1- 12.

Sanjaya, R. (Ed.). 2020. 21 Refleksi Pembelajaran Daring di Masa Darurat. SCU Knowledge Media.

Sugiyono. 2017. Metode Penelitian Kuantitatif, Kualitatif, dan R\&D. Bandung: Alfabeta

Surat Edaran Mendikbud No. 4 Tahun 2020 tentang Pelaksanaan Kebijakan Pendidikan dalam Masa Darurat Penyebaran Coronavirus Disease (Covid2019)

Undang-Undang RI No.20 tahun 2003 tentang Sistem Pendidikan Nasional.

Uno, Hamzah. 2016. Teori Motivasi \& Pengukurannya: Analisis di Bidang Pendidikan. Jakarta:Bumi Aksara.

Yanti, M. T., Kuntarto, E., \& Kurniawan, A. R. 2020. Pemanfaatan Portal Rumah Belajar Kemendikbud Sebagai Model Pembelajaran Daring di Sekolah Dasar. Adi Widya: Jurnal Pendidikan Dasar, 5(1), 61-68. 